[計測自動制御 学会論文集 [ Vol.44, No.5, 415/424 (2008) ]

\title{
On-Off 制御系に対する安定化出カフィードバック則の設計法
}

\author{
赤 阪 大 介**劉 康 志* \\ Design of Stabilizing Output Feedback Control Law for a Class of On-Off Control Systems \\ Daisuke AKASAKA* and Kang-Zhi LiU*
}

\begin{abstract}
In this paper, the stabilization problem of a class of on-off control systems is studied. First, a global stability condition for the state feedback system is derived, which is characterized by a partial differential matrix inequality. Then, a class of state feedback laws which includes nonlinear laws is designed by solving related partial differential equations analytically. Further, the output feedback control design based on a state observer is discussed.
\end{abstract}

Key Words: on-off control systems, global stability, nonlinear feedback law, partial differential equation

\section{1.はじめに}

不連続なリレーアクチュエータを介した on-off 制御は, 古 くから幅広く利用されている制御手法の一つである。たとえ ば，宇宙機の姿勢制御，温度制御，スイッチング回路などに 応用されている。この制御手法がよく用いられる理由は，ア クチュエータ自身の製作コスト, 容量, あるいは消費エネル ギーなどを削減できる所にある，本論文では，Fig. 1 に示す ような不連続リレーによって制御対象を on-off 駆動する制御 系を扱う。このような制御系に対する理論的な解析や設計の 難しさは，やはりアクチュエー夕自身の非線形性や不連続性 にある. 古くは記述関数法などの近似的手法を用いて, 従来 の連続線形システムの立場で解析するという考え方がとられ ていた。これは非常に有用な手法であるが, 近似により解析 の厳密性が欠如するといった問題が生じる，たとえば，非線 形特有の現象を捉えそこなったり, 解析の精度が低ければ, より高性能な制御系の設計が困難となる．近年ではより厳密 な解析が行なわれており，さまざまな解析結果が報告されて (いる ${ }^{5) ~-8)}$. しかしながら，これまで解析が主として行なわれ ており, 厳密かつ統合的な制御系の設計法が確立されている とはいいがたい。

文献 1) において，筆者らは Fig. 1 に示す制御系に対し，制 御対象 $G$ が 2 次の線形システム, $S(x)$ を非線形に拡張され たあるクラスの状態フィードバック則とした場合の安定性に ついて Filippov の枠組みで議論し，非線形フィードバック制 御の有効性を示した。 しかしながら, 制御対象は非常に限定 されており, 状態フィードバック則のクラスは位相平面解析

* 千葉大学工学部 千葉市稲毛区弥生町 1-33

* Faculty of Engineering, Chiba University, Inage-ku, Chiba (Received January 28, 2008)

(Revised April 17, 2008)

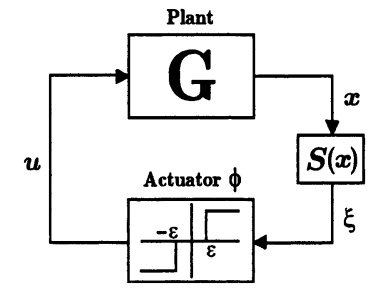

Fig. 1 On-Off control systems

によるものであった.

そこで本論文では, 文献 1) の結果をより一般的な $n$ 次の 線形システムへ拡張し, 非線形な安定化状態フィードバック 則の設計法について提案する，なお，提案する手法は，連立 偏微分方程式の解析解に基づいている．また，オブザーバを 用いた出力フィードバック制御についての検討も行なう.

本論文の特徴として挙げられるのが, 非線形にまで拡張し たフィードバック制御則の設計について考えている点である. これまで on-off 制御系に対する非線形なフィードバック制御 に関する議論はあまりされていない.ここで非線形なフィー ドバック制御を考える理由について述べる. Fig. 1 からも見 て取れるように，アクチュエータ自身は不連続である。した がって, システムにおいて不連続性特有の現象が生じる，た とえば，ワインドアップ，リミットサイクルやチャタリング などが挙げられる。このような非線形システムに対して, 線 形なフィードバック制御のみで高い性能を得ることは難しい. 実際, 飽和要素を含むシステムにおいても非線形なフィード バック制御が有効であるということはよく知られている事実

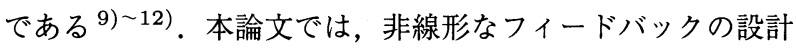
も可能となるような偏微分方程式の解析解に基づいた手法に ついて提案する.

本論文で扱う問題やアプローチは, スイッチング制御 13), 14), Bang-Bang 制御，PWM 型制御入力を用いた手法 ${ }^{15) な と ゙ と ~}$ 
は異なる．詳しい違いについては文献 [1]を参照されたい。ま た，ほかで提案されている離散值入力型システムに対する制 御系設計法 ${ }^{16)}$, 17) とは非線形なフィードバックを考えている 点で異なっている.

本稿は以下のように構成される. まず 2 章において, on-off 制御の定式化を行なう。扱うシステムは不連続であるため, Filippov 解をシステムの解として用いる．つぎに安定性解析 を 3 章で行ない, システムの大域的な安定条件について述べ る. 4 章では, 3 章で得られた安定条件を基に, 状態フィード バック則の設計法を提案する。 そして，5 章でオブザーバを 用いた出力フィードバック安定化について議論し，6 章で具 体的に設計を行ない数值例を示す，最後に 7 章で結論につい て述べる。また本論文では, 行列 $A \in \mathbb{R}^{n \times m}$ に対して, $A^{g}$ を $A$ の一般化逆行列, $A^{+}$を $A$ の疑似逆行列, $\operatorname{ker} A$ を $A$ の 零空間として表記する. 集合 $A \subset \mathbb{R}^{n}$ に対して，その凸包を $\operatorname{co} A$ と表わす.

\section{2. 問題設定}

Fig. 1 に示す状態フィードバック on-off 制御系を考える. $G$ は制御対象， $\phi$ は on-off アクチュエータを表わしており, 両者は互いに状態フィードバック則 $S(x)$ により結合されて いる.

制御対象 $G$ は動的な線形システムであり，その状態方程式 はつぎのように与えられる。

$G: \dot{x}=A x+b u$

ここで, $x \in \mathbb{R}^{n}, u \in \mathbb{R}$ である. また, $(A, b)$ は可制御と仮 定する，さらに，閉ループ系の大域的な安定化を考えるため に，(1) 式に対して以下の仮定を設ける.

[仮定 1] 次式を满たす $P=P^{T} \geq 0(P \neq 0)$ が存在する.

$$
A^{T} P+P A \leq 0
$$

この仮定は, 開ループ系のすべての極が複素平面上の少なく とも閉左半面に存在すること意味する。しかしながら，この 仮定は必ずしも開ループ系の安定性を要求するものではなく, 2 重積分器のような不安定なシステムも含んでいる.

一方, 不連続な on-off アクチュエータの入出力関係 $u=\phi(\xi)$ は次式で与えられる。

$$
u=\phi(\xi)= \begin{cases}\gamma \cdot \operatorname{sgn}(\xi), & \text { if }|\xi|>\epsilon \\ 0, & \text { if }|\xi|<\epsilon \\ \operatorname{co}[0, \gamma], & \text { if } \xi=\epsilon, \epsilon \neq 0 \\ \operatorname{co}[-\gamma, 0], & \text { if } \xi=-\epsilon, \epsilon \neq 0 \\ \operatorname{co}[-\gamma, \gamma], & \text { if } \xi=0, \epsilon=0\end{cases}
$$

ただし， $\gamma>0, \epsilon \geq 0$ を満たす. $\gamma$ は on 入力の大きさを, $\epsilon$ は不感帯の片幅を表わしている。(3) 式において不連続部分

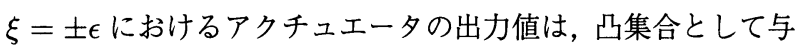
えられている. 本論文では, 閉ループ系の解として Filippov 解を用いるため，(3) 式のような集合值関数の形で不連続な アクチュエータの入出力関係を表現している.
状態フィードバック制御を行なう場合, アクチュエータへの 入力 $\xi$ は $\xi=S(x)$ となる.ここでは非線形を含むできるだけ. 一般的な状態フィードバックを扱うために, $S(x)$ は $S(0)=0$ を満たし，少なくとも $C^{0}$ 級であり，かつ区分的に $C^{1}$ 級で あるという仮定のみを設ける。

以上より, 閉ループ系の微分包含式は次式として表わされる.

$$
\dot{x} \in A x+b \phi(S(x))
$$

以降では，(4) 式の Filippov 解に対する大域的な安定条件を 導出し, 安定化状態フィードバック則の設計による安定化に ついて考えてゆく．また，以降においては (4) 式の Filippov 解は大域的に一意であるという前提で議論を進めてゆく．解 の存在性や一意性については文献 $[1,2]$ を参照されたい.

\section{3. 安定性解析}

本章では, (4) 式で記述される閉ループ系の大域的な安定 条件を導出する.

\section{1 平衡点}

本論文では, (4) 式の右辺が恒等的に零となる $x$ の集合を 閉ループ系の平衡点と呼ぶことにする．考慮している閉ルー プ系の平衡点は, 原点のみになるとは限らず，集合となる場 合もある.これは制御対象, 状態フィードバック則, あるい はアクチュエータにおける不感帯の有無に依存する，以下の 補題で閉ループ系の平衡点について明らかにする.

[補題 1]（4) 式で表わされる閉ループ系の平衡点集合 $\mathcal{N}$ は つぎのように与えられる。

（1） $\operatorname{ker} A \neq\{0\}$ の場合

$$
\mathcal{N}=\left\{x \in \mathbb{R}^{n}:|S(x)| \leq \epsilon, x \in \operatorname{ker} A\right\}
$$

（2） $\operatorname{ker} A=\{0\}$ の場合

$$
\mathcal{N}_{0} \cup\{0\} \subseteq \mathcal{N} \subseteq \mathcal{N}_{0} \cup\{0\} \cup\left\{x_{e+}\right\} \cup\left\{x_{e-}\right\}
$$
ただし，

$$
\begin{aligned}
\mathcal{N}_{0}= & \left\{-A^{-1} b \theta: S\left(-A^{-1} b \theta\right)=\epsilon, \theta \in\left[\begin{array}{ll}
0 \gamma
\end{array}\right]\right\} \\
& \cup\left\{A^{-1} b \theta: S\left(A^{-1} b \theta\right)=-\epsilon, \theta \in\left[\begin{array}{ll}
-\gamma & 0
\end{array}\right]\right\} \\
x_{e+}= & -A^{-1} b \gamma, \quad x_{e-}=A^{-1} b \gamma
\end{aligned}
$$

である.さらに, $x_{e+}, x_{e-} \in \mathcal{N}$ となるための必要十分条件 は，それぞれ $S\left(x_{e+}\right) \geq \epsilon, S\left(x_{e_{-}}\right) \leq-\epsilon$ である.

（証明） 付録 $\mathrm{A}$ を参照.

平衡点の例としてつぎのように $A, b$ が与えられる場合に ついて考える.

$$
A=\left[\begin{array}{cc}
0 & 1 \\
-\mu_{1} & -\mu_{2}
\end{array}\right], \quad b=\left[\begin{array}{l}
0 \\
1
\end{array}\right]
$$

また，簡単のためにフィードバック則 $S(x)=\left[\begin{array}{ll}S_{1} & S_{2}\end{array}\right] x$ は線 形なものとする. まず, $\mu_{1}=0, \mu_{2}>0$ の場合, すなわち, $\operatorname{ker} A \neq\{0\}$ の場合について考える. $\operatorname{ker} A \neq\{0\}$ は $A$ が原 点固有值をもつことを意味している.このとき補題 1 より 
$\mathcal{N}= \begin{cases}\left\{\left(x_{1}, x_{2}\right):\left|x_{1}\right| \leq \frac{\epsilon}{\left|S_{1}\right|}, x_{2}=0\right\} & \text { if } S_{1} \neq 0 \\ \left\{\left(x_{1}, x_{2}\right): x_{2}=0\right\} & \text { if } S_{1}=0\end{cases}$

となる.つぎに, $\mu_{1}, \mu_{2}>0$ の場合について考える.このと き $A$ は明らかに $\operatorname{ker} A=\{0\}$ を満たす．簡単な計算により

$-A^{-1} b \theta=\left[\begin{array}{l}\theta \\ 0\end{array}\right], x_{e+}=\left[\begin{array}{l}\gamma \\ 0\end{array}\right], x_{e-}=\left[\begin{array}{c}-\gamma \\ 0\end{array}\right](11)$

を得ることができ，もし $S_{1}<\epsilon / \gamma$ であれば， $\mathcal{N}_{0}=\emptyset$ と $x_{e+}, x_{e-} \notin \mathcal{N}$ が成立し，(6) 式より $\mathcal{N}=\{0\}$ となる。一 方, $S_{1} \geq \epsilon / \gamma$ の場合, $\mathcal{N}_{0}=\left\{\left[\epsilon / S_{1} 0\right]^{T}\right\} \cup\left\{\left[\begin{array}{lll}-\epsilon / S_{1} & 0\end{array}\right]^{T}\right\}$ と $x_{e+}, x_{e-} \in \mathcal{N}$ が成立し, 複数の平衡点が生じることがわか る.このように，場合によって閉ループ系の平衡点のようす は変化する。

\section{2 大域的な安定定理}

つぎの定理は，閉ループ系の大域的な安定性を保証するた めの十分条件を与える.

《定理 1》以下の二つの条件を満たす行列 $P=P^{T} \geq 0$ と正 定数 $\lambda \in(0,1)$ の存在を仮定する.

（1）つぎの偏微分行列不等式（PDMI）が成立する.

$$
\left[\begin{array}{cc}
A^{T} P+P A & P b+A^{T}\left(\frac{\partial S}{\partial x}\right)^{T} \\
b^{T} P+\frac{\partial S}{\partial x} A & \lambda \frac{\partial S}{\partial x} b+b^{T}\left(\frac{\partial S}{\partial x}\right)^{T} \lambda
\end{array}\right] \leq 0
$$

（2）つぎのリアプノフ関数が半径方向へ非有界となる.

$$
V(x)= \begin{cases}x^{T} P x+2 \gamma(|S(x)|-\epsilon) & \text { if }|S(x)|>\epsilon \\ x^{T} P x & \text { if }|S(x)| \leq \epsilon\end{cases}
$$

このとき，(4) 式の Filippov 解 $x(t)$ は, 大域的に集合 $\Omega_{1} \cup$ $\Omega_{2} \cup \mathcal{N}$ に含まれる最大の不変集合 $\mathcal{V}$ へ収束する.ここで， 集合 $\Omega_{1}, \Omega_{2}$ は

$$
\begin{aligned}
& \Omega_{1}=\left\{x \in \mathbb{R}^{n}: Q x=0,|S(x)|>\epsilon, \frac{\partial S}{\partial x} b=0\right\} \\
& \Omega_{2}=\left\{x \in \mathbb{R}^{n}: Q x=0,|S(x)| \geq \epsilon\right\}
\end{aligned}
$$

で与えられ, $Q$ は

$$
A^{T} P+P A=-Q^{T} Q
$$

を満たす行列である。

（証明） 付録 B を参照.

定理 1 の特徴としてまず挙げられるのが, その安定条件が (12) 式の状態フィードバック則に関する偏微分行列不等式 (以 下, PDMI と略す) で与えられている点である. 設計の際に 問題となるのはをいかにして PDMI を解くかということに なるが，これについては次節で述べる．また，(13) 式のリア プノフ関数は, 通常の $x$ に関する 2 次形式の関数にアクチュ エータに関するポテンシャル関数を加えたものであり，これ はルーリエ系の解析に用いられるルーリエ - ポストニコフ型 のリアプノフ関数である. その意味で定理 1 の安定条件はポ ポフ条件に近いといえる。

定理 1 は, 閉ループ系の Filippov 解が，ある不变集合へ 収束することのみを保証するものであるため，やや瞹昧な結
果であると捉えられるかもしれない. しかしながら，さらに 条件を加えることで平衡点集合 $\mathcal{N} へ$ の収束性を保証するこ とができる，つぎの系は平衡点への収束性に関する結果を与 える，その証明については，付録 C, D を参照.

[系 1] 定理 1 の条件 1 と 2 が成立すると仮定する．任意の $x \in\left\{x \in \mathbb{R}^{n}:|S(x)|>\epsilon\right\} / \mathcal{N}$ に対し，ほとんどすべての時 刻について $\frac{\partial S}{\partial x}(x(t)) b<0$ であるとき, $\mathcal{V} \subset \Omega_{2} \cup \mathcal{N}$ となる. 特に, 行列 $A$ のすべての固有值が, 複素平面上の開左半面か 原点に存在するとき, $\mathcal{V}=\mathcal{N}$ となる.

[系 2] 定理 1 の条件 1 と 2 が成立すると仮定する. $A^{T} P+$ $P A<0$ であるとき, $\mathcal{V}=\mathcal{N}$ となる.

\section{4. 状態フィードバック則の設計}

本章では, 定理 1 の安定条件を基に非線形へ拡張した安定 化状態フィードバック則の設計法を提案する. 定理 1 の安定 条件の中心となるのは (12) 式の PDMI である. (12) 式は状 態フィードバック則 $S(x)$ の偏微分を含んでいるため, $S(x)$ を設計するには (12) 式を解く必要がある．そこで本章では, (12) 式を解析的に解き, その解 $S(x)$ を陽な形で導出するこ とを考える．解法の基本的な指針としては，まず (12) 式を偏 微分行列方程式 (以下, PDME と略す) と不等式の条件に帰 着させ，つぎにその PDMEを解析的に解くことにより， $S(x)$ の形式を陽に得るという考え方である.

つぎの命題は，(12) 式と等価な条件を与える.

[命題］（12) 式が成立することと，つぎの (17)，(18) 式を満 たす $k(x) \in \mathbb{R}^{n}$ が存在することは等価である.

$$
\begin{aligned}
& b^{T} P+\frac{\partial S}{\partial x} A=-k(x)^{T} Q^{T} Q \\
& \frac{\partial S}{\partial x} b+\frac{1}{2 \lambda}\|Q k(x)\|^{2} \leq 0
\end{aligned}
$$

(証明) Schur complement ${ }^{19)}$ より，(12).式は

$$
\operatorname{ker} Q \subset \operatorname{ker}\left(b^{T} P+\frac{\partial S}{\partial x} A\right)
$$

かつ

$\frac{\partial S}{\partial x} b+\frac{1}{2 \lambda}\left(b^{T} P+\frac{\partial S}{\partial x} A\right)\left(Q^{T} Q\right)^{+}\left(b^{T} P+\frac{\partial S}{\partial x} A\right)^{T} \leq 0(20)$ と等価になる。(17) 式において $x$ を固定すると，(17) 式は $k(x)$ に関する線形代数方程式とみなすことができる．零空間 の条件 (19) 式は, まさにその線形代数方程式の解 $k(x)$ が存 在するための必要十分条件となっている. よって, (19) 式が 成立することは，(17) 式を満たすある $k(x)$ が存在すること に等しい. 最後に, (17) 式を (20) 式へ代入することで, (20) 式は

$$
\frac{\partial S}{\partial x} b+\frac{1}{2 \lambda} k(x)^{T} Q^{T} Q\left(Q^{T} Q\right)^{+} Q^{T} Q k(x) \leq 0
$$

となり, 疑似逆行列の性質 $Q^{T} Q\left(Q^{T} Q\right)^{+} Q^{T} Q=Q^{T} Q$ より (18) 式を得る.

命題より, $S(x)$ の設計問題は, 不等式拘束付きの PDME を解く問題へ帰着することがわかる．つぎの定理は，(12) 式 
の PDMI を満たす解の陽な公式を与える。この公式により非 線形な状態フィードバック則の設計も可能となる.

《定理 2》 $f(\cdot), g(\cdot) \in \mathbb{R}$ を区分的な $C^{1}$ 級関数, $k_{0}, k_{1}, l_{0}$, $l_{1} \in \mathbb{R}^{n}$ を定数べクトルとする. また, $\operatorname{ker} A \subset \operatorname{ker} P$ と仮定 する.このとき,つぎの状態フィードバック則 $S(x)$ は, (12) 式の PDMI を満たす.

$$
\begin{aligned}
S(x)= & -\left[\left(b^{T} P+k_{0}^{T} Q^{T} Q\right) A^{g}+l_{0}^{T}\left(I-A A^{g}\right)\right] x \\
& -\int_{0}^{\alpha(x)} f(v) d v-\int_{0}^{\beta(x)} g(w) d w
\end{aligned}
$$

ただし, $\alpha(x), \beta(x)$ は

$$
\begin{aligned}
& \alpha(x)=k_{1}^{T} Q^{T} Q A^{g} x \\
& \beta(x)=l_{1}^{T}\left(I-A A^{g}\right) x
\end{aligned}
$$

で与えられ, 関数 $g(\cdot), h(\cdot)$ と定数べクトル $k_{0}, k_{1}, l_{0}, l_{1}$ は, 不等式 $(25)$ を満たすものである.

$$
\begin{aligned}
& -\left(b^{T} P+k_{0}^{T} Q^{T} Q\right) A^{g} b-l_{0}^{T}\left(I-A A^{g}\right) b \\
& -k_{1}^{T} Q^{T} Q A^{g} b \cdot f(\alpha(x))-l_{1}^{T}\left(I-A A^{g}\right) b \cdot g(\beta(x)) \\
& \quad+\frac{1}{2 \lambda}\left\|Q\left\{k_{0}+k_{1} f(\alpha(x))\right\}\right\|^{2} \leq 0
\end{aligned}
$$

定理 2 において, (22) 式で与えられる状態フィードバック 則は (17) 式の解析解となっている. また，(25) 式の不等式 は (18) 式より導かれている。(22) 式における設計パラメー 夕は, $f(\cdot), g(\cdot), k_{0}, k_{1}, l_{0}, l_{1}$ となり,これらは, (25) 式を 満たす範囲で自由に選ぶことができる。

定理 2 の公式の構造は, 制御対象の性質によって変化する. $A$ が正則の場合, $I-A^{g} A=I-A A^{g}=0$ が成立するため, (22) 式右辺の第 3 項目は消えて, 設計パラメー夕 $g(\cdot)$ に関 する自由度は失われる。一方, $A$ が特異な場合, たとえば, $A$ が原点固有值を含む場合は, $g(\cdot)$ に関する自由度は失われ ない.

[注釈 1] 定理 2 の証明の中で, 関数 $f(\cdot), g(\cdot)$ は $C^{1}$ 級と仮 定しているが，実際，区分的に $C^{1}$ 級としても (22) 式は (17) 式の PDME の解となる．したがって, 定理 2 の中では, $g(\cdot)$, $h(\cdot)$ は区分的に $C^{1}$ 級であるとする.

（定理 2 の証明）まず，(17) 式の PDME を連立偏微分方程 式へ䚻着させる， $x$ を固定すれば，(17) 式は $\partial S / \partial x$ に関す る線形行列方程式とみなすことができるため，それを $\partial S / \partial x$ について解くと, その一般解は

$\frac{\partial S}{\partial x}=-\left(b^{T} P+k(x)^{T} Q^{T} Q\right) A^{g}-l(x)^{T}\left(I-A A^{g}\right)$

で与えられる。ただし,$l(x) \in \mathbb{R}^{n}$ は任意に選ぶことができ る.また，(17) 式が存在するための必要十分条件としてつぎ の代数方程式を満たす必要がある.

$$
\left(b^{T} P+k(x)^{T} Q^{T} Q\right)\left(I-A^{g} A\right)=0
$$

(27) 式は, $\operatorname{ker} A \subset \operatorname{ker} P$ より自動的に成立するが，詳細に ついては証明の最後で述べる.ここで便宜的に，(26) 式にお ける行ベクトル $b^{T} P A^{g}$ の $j$ 番目の要素を $r_{j}$, 行列 $Q^{T} Q A^{g}$,
$I-A A^{g}$ の $j$ 列目のベクトルをそれぞれ $s_{j}, t_{j}$ とおくと, (26) 式は, つぎの $n$ 本の偏微分方程式へ帰着する.

$$
\frac{\partial S}{\partial x_{j}}=-r_{j}-k(x)^{T} s_{j}-l(x)^{T} t_{j}, \quad j=1 \cdots n
$$

つぎに, (28) 式の連立偏微分方程式を解く前に, その解の存 在性について調べなければならない. Compatibility 条件 ${ }^{18)}$ より，(28) 式の連立偏微分方程式が解を有するためには, 任 意の $i, j=1 \cdots n$ について

$\frac{\partial k(x)^{T} s_{j}}{\partial x_{i}}+\frac{\partial l(x)^{T} t_{j}}{\partial x_{i}}=\frac{\partial k(x)^{T} s_{i}}{\partial x_{j}}+\frac{\partial l(x)^{T} t_{i}}{\partial x_{j}}$

が成立する必要がある．そのためには，任意性のある $k(x)$ と $l(x)$ の形式をある程度限定しなければならない.これが得ら れる解の構造やクラスの広さを決定することになる. 実際, 定数べクトル $k_{0}, k_{1}, l_{0}, l_{1} \in \mathbb{R}^{n}, C^{1}$ 級関数 $f(\cdot), g(\cdot)$ と $(23),(24)$ 式で定義される $\alpha(x), \beta(x)$ を用いて

$$
\begin{gathered}
k(x)=k_{0}+k_{1} \cdot f \circ \alpha(x) \\
l(x)=l_{0}+l_{1} \cdot g \circ \beta(x)
\end{gathered}
$$

と選ぶことで $(29)$ 式は満たされる.ただし，(30), (31) 式で 与えられる $k(x), l(x)$ は, $(29)$ 式を満たすすべての $k(x), l(x)$ を表わしているわけではない. その意味では, 解析解 $(22)$ 式 は (12) 式の PDMI を満たすすべての $S(x)$ ではないという ことに注意する．また，(29) 式と (30), (31) 式より任意の $i$, $j=1 \cdots n$ についてつぎの関係が成立する.

$k_{1}^{T} s_{j} \frac{\partial f(\alpha)}{\partial x_{i}}=k_{1}^{T} s_{i} \frac{\partial f(\alpha)}{\partial x_{j}}, \quad k_{1}^{T} t_{j} \frac{\partial g(\beta)}{\partial x_{i}}=k_{1}^{T} t_{i} \frac{\partial g(\beta)}{\partial x_{j}}$ (32) この関係は, 偏微分方程式を解く際に用いられる.

ここから，(28) 式の連立偏微分方程式を解いてゆく.まず, (28) 式の 1 番目 $(j=1)$ の偏微分方程式

$\frac{\partial S}{\partial x_{1}}=-r_{1}-\left\{k_{0}+k_{1} f(\alpha)\right\}^{T} s_{1}-\left\{l_{0}+l_{1} g(\beta)\right\}^{T} t_{1}(33)$ を $x_{1}$ に関して積分すると

$$
\begin{aligned}
S(x)= & -\left(r_{1}+k_{0}^{T} s_{1}+l_{0}^{T} t_{1}\right) x_{1}-k_{1}^{T} s_{1} \int_{0}^{x_{1}} f(\alpha) d x_{1} \\
& -l_{1}^{T} t_{1} \int_{0}^{x_{1}} g(\beta) d x_{1}+S_{1}\left(x_{2}, \cdots, x_{n}\right)
\end{aligned}
$$

となる. 上式を $(28)$ 式の 2 番目 $(j=2)$ の偏微分方程式へ 代入し，整理することで $S_{1}$ に関する偏微分方程式

$$
\begin{aligned}
\frac{\partial S_{1}}{\partial x_{2}}= & -r_{2}-\left\{k_{0}+k_{1} f(\alpha)\right\}^{T} s_{2}-\left\{l_{0}+l_{1} g(\beta)\right\}^{T} t_{2} \\
& +k_{1}^{T} s_{1} \int_{0}^{x_{1}} \frac{\partial f(\alpha)}{\partial x_{2}} d x_{1}+l_{1}^{T} t_{1} \int_{0}^{x_{1}} \frac{\partial g(\beta)}{\partial x_{2}} d x_{1}(35)
\end{aligned}
$$

を得る。(32) 式より

$k_{1}^{T} s_{1} \frac{\partial f(\alpha)}{\partial x_{2}}=k_{1}^{T} s_{2} \frac{\partial f(\alpha)}{\partial x_{1}}, \quad l_{1}^{T} t_{1} \frac{\partial g(\beta)}{\partial x_{2}}=l_{1}^{T} t_{2} \frac{\partial g(\beta)}{\partial x_{1}}(36)$ の関係が成立するので

$k_{1}^{T} s_{1} \int_{0}^{x_{1}} \frac{\partial f(\alpha)}{\partial x_{2}} d x_{1}=k_{1}^{T} s_{2} \int_{0}^{x_{1}} \frac{\partial f(\alpha)}{\partial x_{1}} d x_{1}$ 


$$
\begin{array}{r}
=k_{1}^{T} s_{2} f(\alpha(x))-k_{1}^{T} s_{2} f\left(\alpha\left(0, x_{2}, \cdots, x_{n}\right)\right) \\
l_{1}^{T} t_{1} \int_{0}^{x_{1}} \frac{\partial g(\beta)}{\partial x_{2}} d x_{1}=l_{1}^{T} t_{2} \int_{0}^{x_{1}} \frac{\partial g(\beta)}{\partial x_{1}} d x_{1} \\
=l_{1}^{T} t_{2} g(\beta(x))-l_{1}^{T} t_{2} g\left(\beta\left(0, x_{2}, \cdots, x_{n}\right)\right)
\end{array}
$$

と計算することができる.これらを (35) 式へ代入すると, (35) 式は

$$
\begin{aligned}
\frac{\partial S_{1}}{\partial x_{2}}= & -r_{2}-k_{0}^{T} s_{2}-l_{0}^{T} t_{2}-k_{1}^{T} s_{2} f\left(\alpha\left(0, x_{2}, \cdots, x_{n}\right)\right) \\
& -l_{1}^{T} t_{2} g\left(\beta\left(0, x_{2}, \cdots, x_{n}\right)\right)
\end{aligned}
$$

となる。そして，上式を $x_{2}$ で積分すると

$$
\begin{aligned}
S_{1}\left(x_{2}, \cdots, x_{n}\right)= & -\left(r_{2}+k_{0}^{T} s_{2}+l_{0}^{T} t_{2}\right) x_{2} \\
& -k_{1}^{T} s_{2} \int_{0}^{x_{2}} f\left(\alpha\left(0, x_{2} \cdots, x_{n}\right)\right) d x_{2} \\
& -l_{1}^{T} t_{2} \int_{0}^{x_{2}} g\left(\beta\left(0, x_{2}, \cdots, x_{n}\right)\right) d x_{2} \\
& +S_{2}\left(x_{3}, \cdots, x_{n}\right)
\end{aligned}
$$

となり，上式を再び $(34)$ 式へ代入することで

$$
\begin{aligned}
& S(x)=-\left(r_{1}+k_{0}^{T} s_{1}+l_{0}^{T} t_{1}\right) x_{1}-\left(r_{2}+k_{0}^{T} s_{2}+l_{0}^{T} t_{2}\right) x_{2} \\
& -l_{1}^{T} t_{1} \int_{0}^{x_{2}} g(\beta(x)) d x_{2}-l_{1}^{T} t_{2} \int_{0}^{x_{2}} g\left(\beta\left(0, x_{2}, \cdots, x_{n}\right)\right) d x_{2} \\
& -l_{1}^{T} t_{1} \int_{0}^{x_{2}} g(\beta(x)) d x_{2}-l_{1}^{T} t_{2} \int_{0}^{x_{2}} g\left(\beta\left(0, x_{2}, \cdots, x_{n}\right)\right) d x_{2} \\
& +S_{2}\left(x_{3}, \cdots, x_{n}\right)
\end{aligned}
$$

を得ることができる.

以上のことを $j=n$ まで繰り返し行なうことで, 最終的に 境界条件 $S(0)=0$ を用いて

$$
\begin{aligned}
S(x)= & -\sum_{j=1}^{n}\left(r_{j}+k_{0}^{T} s_{j}+l_{0}^{T} t_{j}\right) x_{j} \\
& -\sum_{j=1}^{n} k_{1}^{T} s_{j} \int_{0}^{x_{j}} f\left(\alpha\left(0, \cdots, 0, x_{j} \cdots, x_{n}\right)\right) d x_{j} \\
& -\sum_{j=1}^{n-1} l_{1}^{T} t_{j} \int_{0}^{x_{j}} g\left(\beta\left(0, \cdots, 0 x_{j}, \cdots, x_{n}\right)\right) d x_{j}(42)
\end{aligned}
$$

を導出することができる. (42) 式右辺の第 1 項目は, - $\left[\left(b^{T} P+\right.\right.$ $\left.\left.k_{0}^{T} Q^{T} Q\right) A^{g}+l_{0}^{T}\left(I-A A^{g}\right)\right] x$ と表わすことができる.つぎ に第 2 項目の積分の和について考えるために, 0 から $x$ まで の任意の積分経路 $C$ をたどる線積分

$$
\int_{C} F(x) \cdot d x
$$

を考える.ただし $F(x), d x \in \mathbb{R}^{n}$ は

$F(x)=\left[\begin{array}{llll}k_{1}^{T} s_{1} & \cdots & k_{1}^{T} s_{n}\end{array}\right]^{T} \cdot f(\alpha(x)), \quad d x=\left[\begin{array}{lll}d x_{1} & \cdots & d x_{n}\end{array}\right]^{T}$

である.(42) 式の第 2 項目は, まさに (43) 式の特別な 積分経路をたどったものとなっている. 全微分 $d \alpha(x)=$ $\sum_{i=1}^{n} k_{1}^{T} s_{i} d x_{i}$ の関係を用いると (43) 式は

$$
\begin{aligned}
\int_{C} F(x) \cdot d x & =\int_{C} f(\alpha(x))\left(\sum_{i=1}^{n} k_{1}^{T} s_{i} d x_{i}\right) \\
& =\int_{C} f(\alpha(x)) d \alpha(x)=\int_{\alpha(0)=0}^{\alpha(x)} f(v) d v(44)
\end{aligned}
$$

となり, (22) 式の第 2 項目の積分と一致する.これは積分値 が積分経路に依存しないことを意味している．同様に (42) 式 の第 3 項目から (22) 式の第 3 項目を導出することができる.

最後に，(25) 式の不等式の導出と (27) 式が成立すること を示す. (12) 式の PDMI を満たすためには, 命題の (18) 式 が成立しなければならないので, (26) 式の $\partial S / \partial x$ を(18) 式 へ代入することで $(25)$ 式の不等式が導出される. また，(27) 式に $(30)$ 式で与えられる $k(x)$ を代入すると

$$
\begin{aligned}
& \left(b^{T} P+k_{0}^{T} Q^{T} Q\right)\left(I-A^{g} A\right)+k_{1}^{T} Q^{T} Q\left(I-A^{g} A\right) \cdot f(\alpha) \\
& =0
\end{aligned}
$$

を得る. 以下, $(45)$ 式が $(A, b)$ 可制御の仮定のもとで $\operatorname{ker} A \subset$ $\operatorname{ker} P$ と等価であることを示す. まず, $A^{T} P+P A=-Q^{T} Q$ の両辺に $\left(I-A^{g} A\right)^{T}, I-A^{g} A$ を掛けると, 一般化逆行列 の性質から $\left(I-A^{g} A\right)^{T} Q^{T} Q\left(I-A^{g} A\right)=0$ を得ることがで きる.これは明らかに $Q\left(I-A^{g} A\right)=0$ と等価である.よっ て, (45) 式は

$$
b^{T} P\left(I-A^{g} A\right)=0
$$

となる. 再び $A^{T} P+P A=-Q^{T} Q$ の右辺から $I-A^{g} A$ を 掛け, $Q\left(I-A^{g} A\right)=0$ を考慮すると，

$$
A^{T} P\left(I-A^{g} A\right)=0
$$

が成立する，そして，(46)，(47) 式を用いて次式を導出する ことができる。

$$
U_{c}^{T} P\left(I-A^{g} A\right)=0
$$

ただし， $U_{c}$ は可制御行列である. $(A, b)$ 可制御であるため, $U_{c}$ は正則となり，(48) 式は $P\left(I-A^{g} A\right)=0$ と等しい。 こ れは $\operatorname{ker} A \subset \operatorname{ker} P$ を意味する。

〔例題】つぎのように $A, b$ が可制御正準形式で与えられる場 合について考える．ただし， $A$ は原点固有值をもつとする.

$$
A=\left[\begin{array}{ccccc}
0 & 1 & & & 0 \\
& & 1 & & \\
\vdots & & & \ddots & \\
& & & & 1 \\
0 & -\mu_{2} & \cdots & & -\mu_{n}
\end{array}\right], \quad b=\left[\begin{array}{c}
0 \\
\vdots \\
0 \\
1
\end{array}\right]
$$

このとき, $A^{g}$ は

$$
A^{g}=\left[\begin{array}{ccccc}
\mu_{2} & \mu_{3} & \cdots & \mu_{n} & 1 \\
1 & & & & 0 \\
& 1 & & & \\
& & \ddots & & \\
0 & \cdots & 0 & 1 & 0
\end{array}\right]
$$


となり

$$
\begin{aligned}
I-A^{g} A & =\operatorname{diag}\{1,0, \cdots, 0\} \\
I-A A^{g}= & {\left[\begin{array}{ccccc}
0 & 0 & \cdots & 0 & 0 \\
\vdots & & & & \vdots \\
0 & 0 & \cdots & 0 & 0 \\
\mu_{2} & \mu_{3} & \cdots & \mu_{n} & 1
\end{array}\right] }
\end{aligned}
$$

と計算することができる。これより不等式 $(25)$ は

$$
-l_{1}^{T} e_{n} \cdot g(\beta(x))+\frac{1}{2 \lambda}\left\|Q\left\{k_{0}+k_{1} f(\alpha(x))\right\}\right\|^{2} \leq 0 \text { (53) }
$$

となる。ただし, $p_{i j}$ は $P$ の $(i, j)$ 要素を, $e_{i} \in \mathbb{R}^{n}$ は $i$ 番目 の要素が 1 の単位べクトルを表わす. 特に $k_{0}=k_{1}=l_{0}=0$, $l_{1}=e_{n}$ と選ぶと, (22) 式は

$$
S(x)=-\sum_{j=1}^{n-1} p_{n(j+1)} x_{j}-\int_{0}^{\beta(x)} g(w) d w
$$

となる。 ただし $\beta(x)=\mu_{2} x_{1}+\cdots+\mu_{n} x_{n-1}+x_{n}$ として 与えられる.また, (53) 式は $g(\cdot) \geq 0$ となる.

\section{5. オブザーバを用いた出カフィードバック安定化}

前章で得られた状態フィードバック則に対して，オブザー バを用いることで制御対象の状態を推定し, 出力フィードバッ クにより安定化を行なう。測定可能な信号は, 制御対象の出 力 $y=C x \in \mathbb{R}^{q}$ とアクチュエータの出力 $\phi$ であり, $(C, A)$ は可検出であると仮定する，状態の推定には，つぎの同一次 元 Luenberger オブザーバを用いる.

$$
\dot{\hat{x}}=(A+L C) \hat{x}+b \phi-L y
$$

上式において $\hat{x}$ は状態 $x$ の推定值を意味する，推定誤差を $e=\hat{x}-x$ と定義し, フィードバック則を $S(\hat{x})$ とすれば, 閉 ループ系全体の微分包含式はつぎのようになる。

$$
\left[\begin{array}{c}
\dot{x} \\
\dot{e}
\end{array}\right] \in\left[\begin{array}{c}
A x+b \phi(S(x+e)) \\
(A+L C) e
\end{array}\right]
$$

つぎの定理で (56) 式の Filippov 解の大域的な安定条件を与 える.

《定理 3》 定理 1 の条件 1 と 2 が成立し, $A+L C$ が安定で あると仮定する。もし，すべての $\|x\| \geq M$ に対して

$$
\left\|\frac{\partial S}{\partial x}(x)\right\|\|\| x \| \leq \rho|S(x)|
$$

となるような正定数 $\rho, M$ が存在すれば, (56) 式の Filippov 解 $(x(t), e(t))$ は大域的に $\mathcal{V} \times\{0\}$ 一収束する.

（証明） 最初に, $(x(t), e(t))$ が任意の時刻 $t \in[0, \infty)$ におい て有界となることを示すことができる。(付録 $\mathrm{E}$ を参照)

つぎに, $(x(t), e(t))$ の収束性について示す. システム全体 に対し, 正定関数 $U(e)=e^{T} P_{e} e$ を時間微分すると $\dot{U}(e)=$ $-e^{T} Q_{e} e<0(e \neq 0)$ となる. すべての $x(t), e(t)$ が有界で あるので, ラサールの不変性原理を適用すると, $(x(t), e(t))$ は $\{(x, e): e=0\}$ に含まれる最大の不変集合に収束するこ
とが保証される． $e=0$ のとき $\dot{x} \in A x+b \phi(S(x))$ となるた

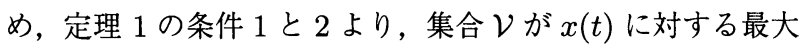
の不変集合となる.よって, $\{(x, e): e=0\}$ に含まれる最大 の不変集合は $\{(x, e): x \in \mathcal{V}, e=0\}$ となり結論を得る. [注釈 2] 定理 3 の条件式 (57) は, $\|x\| \geq M$ において, $S(x)$ の $x$ に関する多項式的な増大が許されることを意味する。つ まり，S(x) が多項式クラスの関数であれば，(57) 式を満たす ような $\rho, M>0$ は必ず存在する.

\section{6. 設計 例}

前章までの結果を基に，安定化状態，および出力フィード バック則の設計手順をまとめると以下のようになる.

（1）状態フィードバック則 $S(x)$ として定理 2 の (22) 式 を用い, (25) 式が成立する範囲で各設計パラメータ $k_{0}, k_{1}$, $l_{0}, l_{1}, f(\cdot), g(\cdot)$ を選ぶ.

（2）(13) 式のリアプノフ関数が半径方向へ非有界となる ことを調べる.

以上より, 定理 1 の安定条件が満たされる. 出力フィードバッ クの場合は上記の手順に加えて

（3）定理 3 の条件 (57) 式が成立するかを確認し，オブ ザーバゲイン $L$ を $A+L C$ が安定となるように選ぶ.

もちろん, あらかじめリアプノフ不等式の解 $P$ の構造を明ら かにし， $S(x)$ の形式を限定することで上記の手順 2,3 にお ける確認作業を省略する設計も可能となる.

ここでは具体的につぎの 4 次の制御対象を状態フィード バック，および出カフィードバックにより大域的に安定化す ることを考える。

$$
G:\left\{\begin{array}{l}
\dot{x}_{i}=x_{i+1} \quad(i=1,2,3) \\
\dot{x}_{4}=-x_{3}-2 x_{4}+u
\end{array}\right.
$$

(58) 式の制御対象は, 2 重積分器と安定な極から構成される 不安定なシステムであり，仮定 1 を満たしている．また，ア クチュエータのパラメータを $\gamma=10, \epsilon=0.01$ と設定する.

(58) 式のシステムは 4 章の例題で扱った可制御正準形式であ $\eta$, 各設計パラメータを $k_{0}=k_{1}=l_{0}=0, l_{1}=\left[\begin{array}{llll}1 & 0 & \cdots & 0\end{array}\right]^{T}$ と選ぶことで, 状態フィードバック則は (54) 式より

$$
S(x)=-p_{42} x_{1}-p_{43} x_{2}-p_{44} x_{3}-\int_{0}^{\beta(x)} g(w) d w(59)
$$

となる.ただし, $\beta(x)=x_{1}+2 x_{2}+x_{3}$ であり, $g(\cdot) \geq 0$ か $つ \operatorname{ker} A \subset \operatorname{ker} P$ を満たす必要がある. 試行錯誤ではあるが, 被積分関数 $g(w)$ を $g(w)=|w| / 12.5 \geq 0$ と選び, リアプノ フ不等式 $A^{T} P+P A \leq 0$ の 1 つの解

$$
P=\left[\begin{array}{cccc}
0 & 0 & 0 & 0 \\
0 & 1 & 2 & 1 \\
0 & 2 & 4.15 & 2.05 \\
0 & 1 & 2.05 & 1.05
\end{array}\right] \geq 0
$$

を用いることで，つぎの状態フィードバック則を得ることが できる。 
$S(x)=-x_{1}-2.05 x_{2}-1.05 x_{3}-\frac{1}{25}|\beta(x)| \beta(x)$

実際，(60)，(61) 式より，(13) 式のリアプノフ関数は半径 方向へ非有界となり, 補題 1 より閉ループ系の平衡点は $\mathcal{N}=\left\{x \in \mathbb{R}^{n}:\left|x_{1}\right| \leq 0.01, x_{2}=\cdots=x_{n}=0\right\}$ とな る. その証明や導出過程については省略する.

以上より, 定理 1 の安定条件が成立することになるが，さら に系 1 の条件が成立し, 状態の $\mathcal{N}$ への収束性が保証されるこ とを以下で示す. まず, $(\partial S / \partial x) b=\partial S / \partial x_{n}=-g(\beta(x))=$ $-|\beta(x)| / 12.5$ より, $\beta(x)=0$ でのみ $(\partial S / \partial x)(t) b \equiv 0$ と なることがわかる. しかしながら， $|S(x)|>\epsilon に$ において $d \beta(x) / d t=\phi= \pm \gamma \neq 0$ が成立するため, ほとんどすべ ての時刻で $(\partial S / \partial x) b<0$ が満たされる。これに制御対象が 積分器と安定な極によって構成されていることを合わせれば, 系 1 より状態の $\mathcal{N}$ への収束性が保証されることになる.

つぎにオブザーバの設計を行なう。ただし, 測定可能な出 力は $y=x_{1}$ とする. (61) 式の状態フィードバックは多項式 オーダーで変化する関数であるため, 定理 3 の (57) 式を満 たすような $\rho, M>0$ を見つけることができる. したがって， (55) 式のオブザーバゲイン $L$ を $A+L C$ が安定になるよう にさえ選べば，システム全体の安定性は保証される。

Fig. 2 に(61) 式の状態フィードバックによる状態の時間 応答，および on-off 制御入力の時間応答を示す。また, Fig. 3 にオブザーバを用いた出力フィードバックの結果を示す。た

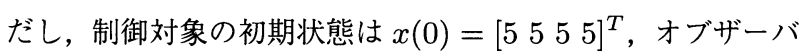
ゲインは $L=\left[\begin{array}{llll}20 & 145 & 418 & 107\end{array}\right]^{T}$, オブザーバの初期状態は 0 とした. 状態, 出カフィードバックの場合ともに状態は平衡 点集合へ収束しているが, 状態フィードバックの結果 Fig. 2 と比べ, 出力フィードバックの場合 Fig. 3 では, 状態の推定 誤差の影響により収束時間が遅れている。また, 制御入力の 切り替え回数がやや増加していることがわかる.

比較として, Fig. 4, 5 にそれぞれ線形な状態, および出 カフィードバック則を用いた場合のシミュレーション結果を 示す. $S(x)$ は

$$
S(x)=-x_{1}-3 x_{2}-2.5 x_{3}-x_{4}
$$

とし，オブザーバには前の非線形な出力フィードバック則と 同じものを用いた（62) 式のフィードバックゲインは, 固定 した初期状態 $x(0)=\left[\begin{array}{llll}5 & 5 & 5 & 5\end{array}\right]^{T}$ に対して, 状態の収束時間 が最も速くなるものを試行錯誤的に選定した.

非線形なフィードバック則による結果 Fig. 2, 3 と比べて, 線形な場合では制御入力にチャタリングが生じている。非線 形なフィードバックの場合のほうが, 確実に切り替えの回数 が少ないことが確認できる。これはアクチュエータ自身への 過負荷, あるいは制御対象の高周波モードが原因となるシス テムの不安定化などを考えれば非常に重要なことである。ま た，切り替え回数だけではなく，アンチワインドアップの効 果により，任意の初期值に対して全体的に速い収束性を実現 できることも確認されており, 非線形なフィードバック則が
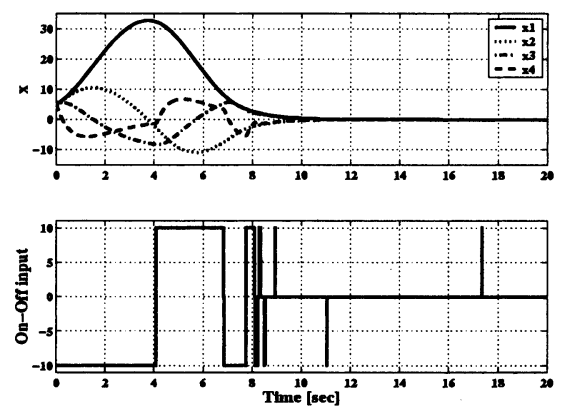

Fig. 2 Time responses by the nonlinear state feedback
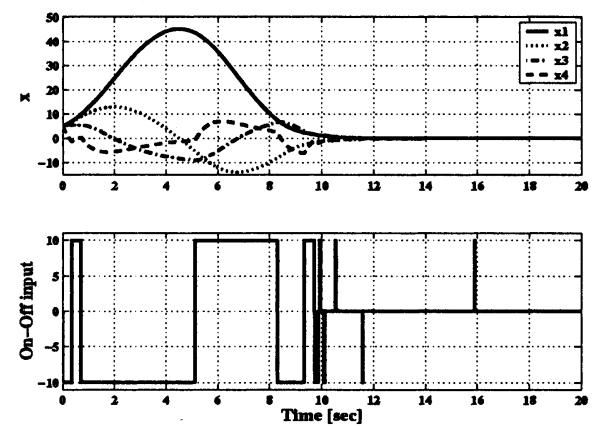

Fig. 3 Time responses by the nonlinear output feedback
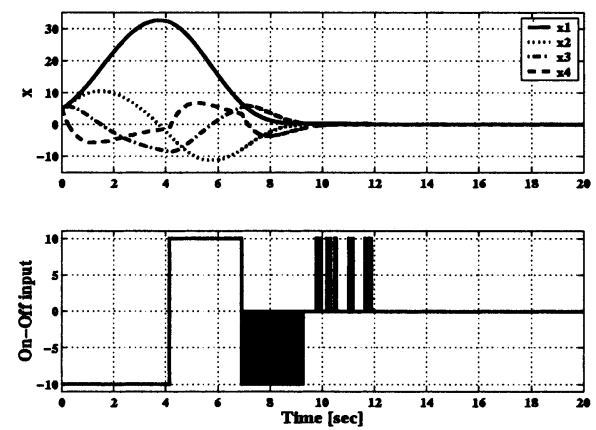

Fig. 4 Time responses by the linear state feedback
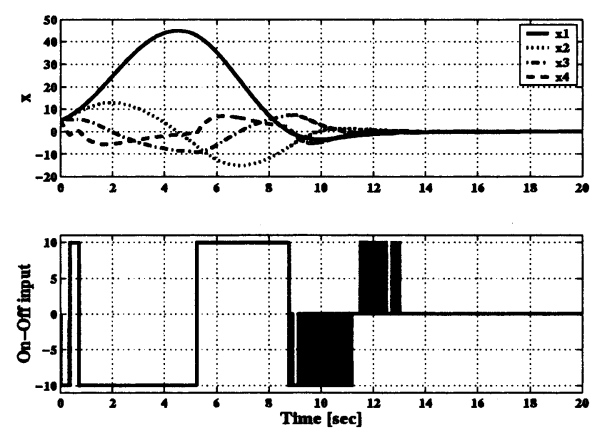

Fig. 5 Time responses by the linear output feedback

高い能力を秘めていることがわかる.

\section{7. 結 論}

本論文では, あるクラスの on-off 制御系に対して, 状態 フィードバック，およびオブザーバを用いた出力フィード バックによる安定化を行なった，主な結果として，まず，非 線形な状態フィードバックも考慮したシステムの大域的な安 
定条件を偏微分行列不等式の形で導出し，その安定条件に関 する偏微分方程式を解析的に解き, 非線形に拡張された安定 化状態フィードバック則をクラスとして陽な形式で導出した。 つぎに, Luenbeger のオブザーバを用いた出カフィードバッ ク制御の場合について, システム全体の安定条件をフィード バック則の増加率に関する条件として導出した。そして，具 体的に設計を行ない, 非線形の制御則が線形なものに比べ，切 り替え回数が少ないという意味で良い性能を発揮できること を例示した。 それに関して, 現在, チャタリングを減らすと いう内容についての論文を投稿準備中である. 本論文の手法 は，飽和要素などを含むシステムにも適応が可能であり，さ らなる発展性が期待できる。

しかしながら, 得られた結果は十分条件であり，安定条件 の保守性の問題やいかにして広いクラスの偏微分方程式解を 得るかなどについて考える必要がある。また，高い性能の制 御系を設計するために，得られたクラスのフィードバック則 の中で最適化を行なうなど, より統合的な設計を目指すこと が課題として挙げられる。

\section{参 考 文 献}

1）赤阪，劉：Filippov の枠組みにおける On-Off 制御系の安定 化, 計測自動制御学会論文集, 43-1 23/30 (2007)

2) A.F. Filippov: Differential equations with discontinuous righthand sides, Kluwer Academic Publishers (1988)

3) D. Shevitz and B. Paden: Lyapunov stability theory of nonsmooth systems, IEEE Trans. Automat. Contr., 39-9, 1910/1914 (1994).

4) F.H. Clarke, Y.S. Ledyaev, R.J. Stern and P.R. Wolenski: Nonsmooth analysis and control theory, graduate texts in mathematics, vol. 178, Springer-Verlag, New York (1998)

5) Y.Z. Tsypkin: Relay control systems, Cambridge U.K.: Cambridge Univ. Press (1984)

6) K.J. Åström: Oscillations in systems with relay feedback, IMA Vol. Math. Appl.: Adapt. Control, Filitering, Signal Processing, vol. 74, 1/25 (1995)

7) J.M. Gonçalves, A. Megretski and M.A. Dahleh: Global stability of relay feedback systems, IEEE Trans. Automat. Contr., 46-4, 550/562 (2001)

8) K.H. Johansson, A.E. Barabanov and K.J. Åström: Limit cycles with chattering in relay feedback systems, IEEE Trans. Automat. Contr., 47-9, 1414/1423 (2002)

9) T. Hu and Z. Lin: Composite quadratic lyapunov functions for constrained control systems, IEEE Trans. Automat. Contr., 48-3, 440/450 (2003)

10) B.M. Chen, T.H. Lee, K. Peng and V. Venkataramanan: Composite nonlinear feedback control for linear systems with input saturation: theory and an application, IEEE Trans. Automat. Contr. 48-3, 427/439 (2003)

11) A. Bemporad, M. Morari, V. Dua and E.N. Pistikopoulos: The explicit linear quadratic regulator for constrained systems, Automatica, 38-1, 3/20 (2002)

12）和田, 佐伯: 入力飽和システムの Anti-windup 制御, システ 么/制御/情報，46-2，84/90 (2002)

13) D. Liberzon: Switching in Systems and Control, Birkhäuser (2003)

14) Z. Sun and S.S. Ge: Switched Linear Systems, Control and Design, Springer-Verlag (2005)

15）冨田，浅井：PWM 型制御入力に基づく安定化制御，計測自 動制御学会論文集， 42-2, 129/138 (2006)
16）南, 東, 杉江: 離散值入力型フィードバック制御における最適動 的量子化器, 計測自動制御学会論文集, 43-3, 227/233 (2007)

17）神谷, 内田：スライディングモードを利用した離散入力システ ムの制御, 計測自動制御学会論文集, 43-6, 439/446 (2007)

18) D. Zwillinger: Handbook of Differential Equations, Academic Press (1992)

19) E. Kreindler and A. Jameson: Conditions for nonnegativeness of partitioned matrices, IEEE Trans. Automat. Contr., 17-1, 147/148 (1972)

\section{《付録》}

\section{A. 補題 1 の証明}

平衡点において, (4) 式の右辺が零となるので

$A x+b \phi=0$

を満たす $x$ の集合について以下で調べてゆく

まず, $\operatorname{ker} A \neq\{0\}$ の場合について示す. $|S(x)|<\epsilon に お ~$ いて $\phi=0$ となるため, 明らかに $x \in \operatorname{ker} A$ は平衡点とな る. 一方, $|S(x)|>\epsilon$ において平衡点は $A x \pm b \gamma=0$ を満 たす． $A x \pm b \gamma=0$ を満たす $x$ が存在するための必要十分条 件は, $\operatorname{rank}[A b]=\operatorname{rank} A$ が成立することである。しかし ながら, $\operatorname{ker} A \neq\{0\}$ より $\operatorname{rank} A \leq n-1,(A, b)$ 可制御よ り $\operatorname{rank}[A b]=n$ となるため, $\operatorname{rank}[A, b]=\operatorname{rank} A$ は成立 しない. よって, $|S(x)|>\epsilon に お い て$ 平衡点は存在しない. 最後に不連続面 $S(x)= \pm \epsilon$ であるが, この領域では $\phi$ の値 が集合として与えられている， $\phi=0$ の場合は， $|S(x)|<\epsilon$ の場合と同様に考えることができるため, $S(x)= \pm \epsilon に お ~$ いても $x \in \operatorname{ker} A$ は平衡点となる。一方， $\phi \neq 0$ の場合は, $|S(x)|>\epsilon$ の場合と同じ理由で平衡点は存在しない. 以上よ り, 平衡点集合は (5) 式で与えられる.

つぎに, $\operatorname{ker} A=\{0\}$ の場合について示す。このとき $A^{-1}$ が存在するため, 平衡点は $x=-A^{-1} b \phi$ を満たす。したがっ て, $|S(x)| \leq \epsilon$ では, $x \in \mathcal{N}_{0} \cup\{0\}$ が確実に平衡点とな るため, $\mathcal{N}_{0} \cup\{0\} \subseteq \mathcal{N}$ の関係が成立する. $|S(x)|>\epsilon て ゙$ は, $S\left(x_{e+}\right)>\epsilon$ のときにのみ $x_{e+} \in \mathcal{N}$ となり, 同様に, $S\left(x_{e-}\right)<-\epsilon$ のときにのみ $x_{e-} \in \mathcal{N}$ となる．以上より， $\mathcal{N} \subseteq \mathcal{N}_{0} \cup\{0\} \cup\left\{x_{e+}\right\} \cup\left\{x_{e-}\right\}$ から (6) 式が導かれる.

\section{B. 定理 1 の証明}

つぎの補題は定理 1 の証明に用いられる.

[補題 2] (12) 式を満たす $P=P^{T} \geq 0$ と $\lambda \in(0,1)$ が存 在することは

$\left[\begin{array}{cc}\lambda_{1}\left(A^{T} P+P A\right) & P b+A^{T}\left(\frac{\partial S}{\partial x}\right)^{T} \\ b^{T} P+\frac{\partial S}{\partial x} A & \lambda_{2} \frac{\partial S}{\partial x} b+b^{T}\left(\frac{\partial S}{\partial x}\right)^{T} \lambda_{2}\end{array}\right] \leq 0$

を満たす $P=P^{T} \geq 0$ と $\lambda_{1}, \lambda_{2} \in(0,1)$ が存在することに 等しい.

（証明） (12) 式を満たす $\lambda \in(0,1)$ が存在すれば, $\lambda=\lambda_{1} \lambda_{2}$ となるような $\lambda_{1}, \lambda_{2} \in(0,1)$ は必ず存在する. (12) 式におい て $\lambda=\lambda_{1} \lambda_{2}$ とおき, $\operatorname{diag}\left\{\sqrt{\lambda_{1}} I, \frac{1}{\sqrt{\lambda_{1}}}\right\}$ で合同変換を行なえ ば，等価的に (B. 1) 式を得る。逆に，(B.1) 式を満たす $\lambda_{1}$, $\lambda_{2} \in(0,1)$ が存在すれば. $\lambda=\lambda_{1} \lambda_{2} \in(0,1)$ となり, 同じ 
合同変換により (12) 式を得る.

定理 1 の証明にはリアプノフの安定論を用いるが, Filippov 解はすべての時刻について滑らかであるとは限らず，(13) 式

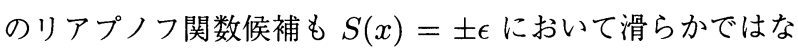
い.したがって, より厳密に証明するためには滑らかでないシ ステムのリアプノフ安定論3)の枠組みで議論する必要がある.

$P \geq 0$ と条件 2 より，(13) 式で与えられるリアプノフ関数 $V(x)$ は, $V(x) \geq 0$ を満たし, かつ半径方向に非有界となる. さらに, $V(x)$ は正則関数 ${ }^{4)}$ である. 以下では, その $V(x)$ に 対する一般化時間微分 $\dot{\tilde{V}}(x)$ を計算してゆく.

$$
\dot{\tilde{V}}(x)=\bigcap_{\forall \xi \in \partial V(x)} \xi^{T}(A x+b \phi)
$$

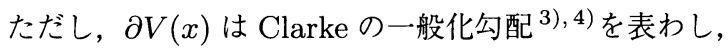

$$
\partial V(x)=\operatorname{co}\left\{\lim _{x_{i} \rightarrow x} \nabla V, x_{i} \notin \mathcal{S}\right\}
$$

で定義される．ここで，集合 $\mathcal{S}$ は， $V(x)$ の勾配が定義され ない測度ゼロの集合である。

i) $|S(x)| \neq \epsilon$ の場合

領域 $|S(x)| \neq \epsilon$ において, $V(x)$ は $x$ に関して一階微分可 能であるため, $\dot{\tilde{V}}$ は通常の時間微分と一致し

$\dot{\tilde{V}}(x)=z^{T}\left[\begin{array}{cc}A^{T} P+P A & P b+A^{T}\left(\frac{\partial S}{\partial x}\right)^{T} \\ b^{T} P+\frac{\partial S}{\partial x} A & \frac{\partial S}{\partial x} b+b^{T}\left(\frac{\partial S}{\partial x}\right)^{T}\end{array}\right] z$

となる。ただし， $z=\left[x^{T}, \phi\right]^{T}$ とおいた。 さらに， $\lambda_{1}, \lambda_{2} \in$ $(0,1)$ を用いて (B. 4) 式を変形すると次式が得られる.

$$
\begin{aligned}
\dot{\tilde{V}}(x)= & z^{T}\left[\begin{array}{cc}
\lambda_{1}\left(A^{T} P+P A\right) & P b+A^{T}\left(\frac{\partial S}{\partial x}\right)^{T} \\
b^{T} P+\frac{\partial S}{\partial x} A & \lambda_{2} \frac{\partial S}{\partial x} b+b^{T}\left(\frac{\partial S}{\partial x}\right)^{T} \lambda_{2}
\end{array}\right] z \\
& -\left(1-\lambda_{1}\right)\|Q x\|^{2}+2\left(1-\lambda_{2}\right) \frac{\partial S}{\partial x} b \phi^{2}
\end{aligned}
$$

上式の右辺第 1 項に対して補題 2 を用いると

$$
\dot{\tilde{V}}(x) \leq-\left(1-\lambda_{1}\right)\|Q x\|^{2}+2\left(1-\lambda_{2}\right) \frac{\partial S}{\partial x} b \phi^{2}
$$

が成立し， $\lambda_{1}, \lambda_{2} \in(0,1)$ と $\frac{\partial S}{\partial x} b \leq 0$ より， $\dot{\tilde{V}} \leq 0$ となる. また, $\dot{\tilde{V}}=0$ を満たす $x$ の集合を調べると, (B. 6) 式より, $|S(x)|>\epsilon$ の領域においては集合 $\Omega_{1}$ でのみ $\dot{\tilde{V}}(x)=0$ となり うる. 同様に $|S(x)|<\epsilon$ の領域では集合 $\Omega_{2}$ でのみ $\dot{\tilde{V}}(x)=0$ となることがわかる.

ii) $|S(x)|=\epsilon$ の場合

$$
\begin{gathered}
|S(x)|=\epsilon \text { において, Clarke の一般化勾配 } \partial V(x) \text { は } \\
\partial V(x)=2 P x+2\left(\frac{\partial S}{\partial x}\right)^{T} \delta(S(x))
\end{gathered}
$$

となる.ただし, 関数 $\delta(\eta)$ は次式で定義される.

$$
\delta(\eta)= \begin{cases}\operatorname{co}[0, \gamma] & \text { if } \eta=\epsilon, \epsilon \neq 0 \\ \operatorname{co}[-\gamma, 0] & \text { if } \eta=-\epsilon, \epsilon \neq 0 \\ \operatorname{co}[-\gamma, \gamma] & \text { if } \eta=0, \epsilon=0\end{cases}
$$

$\xi=\partial V(x)$ として, $\xi^{T}(A x+b \phi)$ へ代入し, 簡単な計算を行 なうことで

$$
\begin{gathered}
\xi^{T}(A x+b \phi)=z^{T}\left[\begin{array}{cc}
A^{T} P+P A & P b+A^{T}\left(\frac{\partial S}{\partial x}\right)^{T} \\
b^{T} P+\frac{\partial S}{\partial x} A & \frac{\partial S}{\partial x} b+b^{T}\left(\frac{\partial S}{\partial x}\right)^{T}
\end{array}\right] z \\
-2 \frac{\partial S}{\partial x}(A x+b \phi) \phi+2 \frac{\partial S}{\partial x}(A x+b \phi) \delta(S(x))
\end{gathered}
$$

を得ることができる． $\frac{\partial S}{\partial x}(A x+b \phi)=0$ の場合，すなわち， $x(t)$ が $S(x)=\epsilon$ に拘束される場合 ${ }^{(\text {注 } 1)}, \dot{\tilde{V}}$ は

$$
\dot{\tilde{V}}=z^{T}\left[\begin{array}{cc}
A^{T} P+P A & P b+A^{T}\left(\frac{\partial S}{\partial x}\right)^{T} \\
b^{T} P+\frac{\partial S}{\partial x} A & \frac{\partial S}{\partial x} b+b^{T}\left(\frac{\partial S}{\partial x}\right)^{T}
\end{array}\right] z
$$

となる.これは $|S(x)| \neq \epsilon$ の場合における (B.4) 式と一致し, 同様に $\dot{\tilde{V}}(x) \leq 0$ を示すことができる. 一方, $\frac{\partial S}{\partial x}(A x+b \phi) \neq 0$ の場合は $\dot{\tilde{V}}=\emptyset$ となるため, これ以上考える必要はない。ま た，集合 $\Omega_{2}$ においてのみ $\dot{\tilde{V}}(x)=0$ となることも明らかで ある。

以上より，すべての $x \in \mathbb{R}^{n}$ に対して $\dot{\tilde{V}}(x) \leq 0$ を示すこ とができた. ラサールの不变性原理 ${ }^{3)}$ より, Filippov 解 $x(t)$ は, $\Omega=\Omega_{1} \cup \Omega_{2} \cup \mathcal{N}$ に含まれる最大の不变集合 $\mathcal{V}$ 一収束 することが保証される。

\section{C. 系 1 の証明}

(B. 6) 式においてほとんどすべての時刻で $\frac{\partial S}{\partial x} b<0$ とな れば, $|S(x)|>\epsilon$ の領域で $\dot{\tilde{V}} \equiv 0$ とはならない. よって, $\mathcal{V} \subset \Omega_{2} \cup \mathcal{N}$ となる.

つぎに，Aのすべての固有值が開左半面および原点に存在 するとき, $\mathcal{V}=\mathcal{N}$ となることを証明する，そこでまず, $\mathcal{V} に$ おいて，閉ループ系のダイナミクスは $\dot{x}=A x$ となることを 示す. $\mathcal{V} \subset \Omega_{2} \cup \mathcal{N}$ より, $\mathcal{V} \subset\{x:|S(x)| \leq \epsilon\} \cup \mathcal{N}$ が成立 し, $|S(x)|<\epsilon$ では制御入力が零となるので明らかに $\dot{x}=A x$ となる. $|S(x)|=\epsilon$ では, ほとんどすべての時刻で $\frac{\partial S}{\partial x} b<0$ が成立しているので, (B.6) 式より $\dot{\tilde{V}} \equiv 0$ となりうるのは, $\phi \equiv 0$ のときのみとなる.よって，Vにおいて閉ループ系の ダイナミクスは $\dot{x}=A x$ となる.

$A$ が安定な固有值のみで構成される場合, 不変集合 $\mathcal{V}$ 内で 常に $\dot{x}=A x$ となることから, $x(t)$ は必ず平衡点へ漸近収束 する.よって，V $=\mathcal{N}$ となる．また， $A$ が安定な固有值と 原点固有值で構成される場合, $x(t)$ は必ず平衡点へ収束する か, あるいは, Vの外側へ出てしまう。.これは $A$ が原点固有 值をもつために起こりえる，Aが 1 つの原点固有值をもつと き, $\mathcal{V} / \mathcal{N}$ から出発する $\dot{x}=A x$ の解は $t \rightarrow \infty$ である点へ 収束する，その収束先の点がVに含まれていれば，その点は 閉ループ系の平衡点となっている。一方, その収束先の点が Vに含まれていなければ, $x(t)$ はVの外に出てしまう。これ はV が不変集合であることに矛盾する．よってV $=\mathcal{N}$ とな る. $A$ が 2 つ以上の原点固有值をもつとき, $\mathcal{V} / \mathcal{N}$ から出発 する $\dot{x}=A x$ の解は $t \rightarrow \infty$ で発散する. 定理 1 より閉ルー

(注 1) $\dot{S}(x)=\frac{\partial S}{\partial x}(A x+b \phi)$ となることより，上記の条件は $\dot{S}(x)=0$ を意味する。 
プ系の状態が発散することはないので, $V=\mathcal{N}$ とならなけれ ばならない。

\section{D. 系 2 の証明}

$A^{T} P+P A<0$ のとき, $\Omega_{1}=\Omega_{2}=\{0\}$ となるので $\mathcal{V}=\mathcal{N}$ となる.

\section{E. 有界性の証明}

定理 2 の条件が成立するとき，(56) 式の Filippov 解 $(x(t), e(t))$ が $t \in[0, \infty)$ において有界となることをつぎの関 数 $W(x, e)$ を用いて示す.

$W(x, e)=\left\{\begin{array}{ll}x^{T} P x+e^{T} P_{e} e+2 \gamma\{|S(x+e)|-\epsilon\} & \text { if } S(x+e)>\epsilon \\ x^{T} P x+e^{T} P_{e} e & \text { if } S(x+e) \leq \epsilon\end{array}(\right.$ E. 1$)$

ただし， $P_{e}=P_{e}^{T}>0$ は,つぎのリアプノフ方程式の解で ある。

$$
P_{e}(A+L C)+(A+L C)^{T} P_{e}+Q_{e}=0 .
$$

$A+L C$ は安定であるため, 任意の $Q_{e}=Q_{e}^{T}>0$ に対して 必ずある $P_{e}=P_{e}^{T}>0$ が存在する.

まず, $W(x, e)$ は, $W(x, e) \geq 0$ を満たし, かつ半径方向 へ非有界となることを示す. $W(x, e) \geq 0$ は定理 1 の条件と $P_{e}>0$ から明らかである.つぎに, $\|v\|=1$ を満たす任意の ベクトル $v \in \mathbb{R}^{2 n}$ を $v_{1}, v_{2} \in \mathbb{R}^{n}$ を用いて $v=\left[v_{1}^{T} v_{2}^{T}\right]^{T}$ と 表わす. そして, (E. 1) 式に $\left[x^{T} e^{T}\right]^{T}=\tau\left[\begin{array}{ll}v_{1}^{T} & v_{2}^{T}\end{array}\right]^{T}$ を代入 し, $\tau \rightarrow \infty$ としたときに, 任意の $v$ に対して $W=\infty$ となれ ば, $W$ は半径方向へ非有界となる. $v_{2} \neq 0$ の場合, $\tau \rightarrow \infty$ とすると, $v_{2}^{T} P_{e} v_{2} \neq 0$ より $W=\infty$ となることがわかる. 一方, $v_{2}=0$ の場合, (E. 1$)$ 式は定理 1 における (13) 式のリ アプノフ関数 $V(x)$ と一致する. すなわち, $W(x, 0)=V(x)$ となる.よって, 定理 1 の条件 2 より $V(x)$ は半径方向へ 非有界となるため, $\tau \rightarrow \infty$ で $W=\infty$ となる. 以上より, (E. 1) 式は半径方向へ非有界となる.

[補題 3] もし定理 3 の (57) 式が成立すれば, $\|x\| \geq M に$ 対して

$$
|\phi(S(\hat{x}))|\left\|\frac{\partial S}{\partial \hat{x}}(\hat{x})\right\| \leq \frac{\rho}{2 M} W(x, e)+\frac{\rho \gamma \epsilon}{M}
$$

が成立する。

（証明）まず，つぎの関係が成立することを示す。

$$
\frac{1}{2} W(x, e)+\gamma \epsilon \geq|\phi(S(\hat{x}))||S(\hat{x})|
$$

(E. 1) 式より

$$
W(x, e) \geq 2|\phi(S(\hat{x}))||S(\hat{x})|-2|\phi(S(\hat{x}))| \epsilon
$$

が成立するので

$$
\frac{1}{2} W(x, e)+|\phi(S(\hat{x}))| \epsilon \geq|\phi(S(\hat{x}))||S(\hat{x})|
$$

と $\gamma \geq|\phi|$ より,(E.4) 式を得る.

(E. 3 ) 式はすべての $\|x\| \geq M$ に対して

$\left\|\phi \frac{\partial S}{\partial \hat{x}}\right\| \leq|\phi|\left\|\frac{\partial S}{\partial \hat{x}}\right\| \leq \rho \frac{|\phi \| S(\hat{x})|}{\|x\|} \leq \frac{\rho W}{2 M}+\frac{\rho \gamma \epsilon}{M}$
が成立することより示される，上式を左から見て，最初の不 等号は明らかであり，2 番目の不等号は定理 3 の (57) 式より 成立する. 最後に 3 番目の不等号は (E. 4$)$ 式と $\|x\| \geq M$ か ら導かれる。

$W(x, e)$ の一般化時間微分 $\dot{\tilde{W}}$ はつぎの関係を満たす.

$$
\dot{\tilde{W}}(x, e) \leq 2 \phi(S(\hat{x})) \frac{\partial S}{\partial \hat{x}}(\hat{x})(A+L C) e
$$

上式は, 定理 1 の条件 1 と $e^{T} Q_{e} e \geq 0$ から容易に得ることが できる. また, $A+L C$ は安定であるので, $\dot{e}=(A+L C) e よ り$ $\|e(t)\| \leq k_{a}(e(0)) \exp (-a t)$ となるようなある $k_{a}(e(0))>0$ と $a>0$ が存在し

$$
\begin{aligned}
\dot{\tilde{W}}(x, e) & \leq 2 \phi \frac{\partial S}{\partial \hat{x}}(A+L C) e \leq 2|\phi|\left\|\frac{\partial S}{\partial \hat{x}}\right\|\|A+L C\|\|e\| \\
& \leq 2|\phi|\left\|\frac{\partial S}{\partial \hat{x}}\right\|\|A+L C\| k_{a}(e(0)) \exp (-a t) \text { (E. 9) }
\end{aligned}
$$

が成立する．さらに，(E.9) 式に対して補題 3 を用いると $\dot{\tilde{W}} \leq K_{1}(e(0)) W \exp (-a t)+K_{2}(e(0)) \exp (-a t)(\mathrm{E} .10)$ が $\|x\| \geq M$ に対して成立する.ただし，

$$
\begin{aligned}
& K_{1}(e(0))=\rho M^{-1}\|A+L C\| k_{a}(e(0)) \\
& K_{2}(e(0))=2 \rho \gamma \epsilon M^{-1}\|A+L C\| k_{a}(e(0))
\end{aligned}
$$

とおいた．以上より，ほとんどすべての時刻において $\dot{W} は$ $\dot{W} \leq K_{1}(e(0)) W \exp (-a t)+K_{2}(e(0)) \exp (-a t)(\mathrm{E} .13)$ の関係を満たす. 最後に, 比較定理を用いることで, $\|x\| \geq M$ に対して,つぎのような $W(x(t), e(t))$ に関する上界を得る ことができる。

$W(t) \leq\left(W(0)+\frac{K_{2}(e(0))}{a}\right) \exp \left(\frac{K_{1}(e(0))}{a}\right)$

$W(x, e)$ は, $(x, e)$ に関してリプシッッ連続，下に有界，かつ 半径方向へ非有界であるため, (E. 14) 式は, $t \in[0, \infty)$ にお いて $(x(t), e(t))$ が有界となることを意味する.

\section{[著 者 紹 介]}

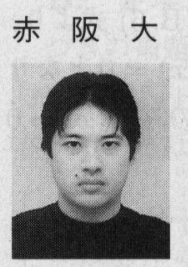

\section{(学生会員)}

2006 年千葉大学自然科学研究科博士前期課程修 了, 現在同大学同研究科人工システム科学専攻博 士後期課程に所属. 切り替え制御や非線形制御な どに興味をもつ。

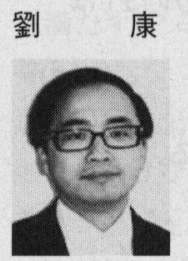

志 (正会員)

1984 年中国西北工業大学卒業, 91 年千葉大学 大学院学術博士, 96 年より千葉大学工学部助教授, 現在同学部准教授.ロバスト制御，適応制御，非 線形制御の研究に従事. 著書「線形ロバス卜制御」 (コロナ社)，共著「現代制御理論通論」(培風館), 共訳「ロバスト最適制御」(コロナ社). 